\title{
PENGARUH KOMUNIKASI KEPALA SEKOLAH DAN IKLIM KERJA ORGANISASI SEKOLAH TERHADAP KINERJA GURU SD NEGERI DI KECAMATAN MATARAM KOTA MATARAM
}

\author{
Mudena $^{1}$, Sudirman Wilian ${ }^{2}$, Sukardi $^{3}$ \\ Program Studi Magister Administrasi Pendidikan ${ }^{123}$ \\ Program Pascasarjana Universitas Mataram ${ }^{123}$ \\ Email: mudena10@gmail.com
}

\begin{abstract}
Abstrak: Tujuan penelitian ini adalah untuk mengetahui pengaruh antara pelaksanaan komunikasi kepala sekolah dan iklim kerja organisasi sekolah terhadap kinerja guru secara sendiri-sendiri maupun secara bersama-sama dengan kualitas pembelajaran pada sekolah dasar negeri di Kecamatan Mataram Kota Mataram. Untuk memperoleh data dalam penelitian adalah menggunakan metode ex-post fakto. Populasi dalam penelitian ini adalah seluruh guru sekolah dasar negeri di Kecamatan Mataram. Sampel penelitian sebanyak 60 orang guru yang ditentukan dengan teknik simple random sampling. Teknik pengumpulan data menggunakan kuesioner. Analisis data menggunakan uji regresi dan korelasi. Hasil penelitian menemukan ada pengaruh positif dan signifikan antara komunikasi kepala terhadap kinerja guru, iklim kerja organisasi sekolah terhadap kinerja serta komunikasi kepala sekolah dan iklim kerja organisasi sekolah secara bersama-sama terhadap kinerja guru sekolah dasar negeri di Kecamatan Mataram Kota Mataram. Dapat direkomendasikan dari uji komparasi dan uji statistik ternyata secara bersama-sama komunikasi kepala sekolah dan iklim kerja organisasi sekolah terhadap kinerja guru memberikan kontribusi yang lebih positif dan signifikan daripada secara parsial.
\end{abstract}

Kata kunci : kinerja guru , komunikasi kepala sekolah, iklim kerja organisasi sekolah.

\begin{abstract}
The purpose of this study was to determine the effect of the implementation of communication principals and school climate organizational work on teacher performance individually or jointly with the quality of teaching in public elementary schools in the District Mataram Mataram. To obtain the data in the study is using ex-post facto. The population in this study are all public primary school teachers in the district of Mataram. The research sample as many as 60 teachers are determined by simple random sampling technique. The technique of collecting data using questionnaires. Data analysis using regression and correlation. The study found no positive and significant influence between communication head on teacher performance, school climate organizational work on the performance and communication of climate principals and school organization work together on the performance of public primary school teachers in the district of Kota Mataram. Can be recommended from statistical comparison test and the test turned out jointly communication principals and school climate organizational work on teacher performance contributes to a more positive and significant than partially.
\end{abstract}

Keywords: teacher performance, communication principals, school organizations working climate. 


\section{A. PENDAhuluaN}

Pendidikan adalah salah satu institusi yang berperan menyiapkan sumber daya manusia. Sejalan dengan perkembangan zaman, tantangan yang dihadapi sistem pendidikan semakin meningkat baik kualitas, kuantitas maupun relevansinya. Perkembangan masyarakat yang diikuti dengan perkembangan kebutuhannya memunculkan jenis dan bentuk pekerjaan baru yang memerlukan penyesuaian spesifikasi kemampuan dan persyaratan dari tenaga kerjanya, As'ari (Carudin 2011:131). Arus globalisasi menimbulkan tantangan daya saing terhadap produk barang dan jasa. Sistem pendidikan yang bermutu akan mampu meningkatkan kualitas sumber daya manusia. Pada akhirnya kualitas produk barang dan jasa menjadi meningkat sehingga diharapkan mampu menjadi tuan rumah di negerinya sendiri dan dapat bersaing di pasar global.

Guru merupakan faktor sentral di dalam sistem pembelajaran terutama di sekolah. Semua komponen lain, mulai dari kurikulum, sarana-prasarana, biaya, dan sebagainya tidak akan banyak berarti apabila keutamaan pembelajaran yaitu interaksi guru dengan peserta didik tidak berkualitas. Semua komponen lain, terutama kurikulum akan "hidup" apabila dilaksanakan oleh guru. Peranan guru sangat penting dalam mentransformasikan input pendidikan, sehingga dapat dipastikan bahwa di sekolah tidak akan ada perubahan atau peningkatan kualitas tanpa adanya perubahan dan peningkatan kualitas guru. Hal ini berarti, pendidikan yang baik dan unggul tetap akan bergantung pada kinerja guru.

Mengingat pentingnya guru, maka kinerja guru harus selalu dikontrol dan ditingkatkan. Sayangnya, dalam kultur masyarakat Indonesia sampai saat ini pekerjaan guru masih cukup tertutup. Bahkan atasan guru seperti kepala sekolah dan pengawas sekali pun tidak mudah untuk mendapatkan data dan mengamati realitas keseharian performance guru di hadapan siswa. Guru berusaha menampakkan kinerja terbaiknya, baik pada aspek perencanaan maupun pelaksanaan pembelajaran hanya pada saat dikunjungi. Selanjutnya guru akan kembali bekerja seperti sedia kala, kadang tanpa persiapan yang matang serta tanpa semangat dan antusiasme yang tinggi.

Menurut Rivai V. (2009), "Kinerja adalah perilaku yang nyata yang ditampilkan setiap orang sebagai prestasi kerja sesuai dengan peranannya". Kinerja merupakan suatu wujud prilaku seseorang atau organisasi dengan orientasi prestasi. Kinerja guru dapat dilihat dan diukur berdasarkan spesifikasi kompetensi yang harus dimiliki oleh guru. Indikator penilaian terhadap kinerja guru dilakukan terhadap tiga kegiatan pembelajaran di kelas yaitu: Perencanaan kegiatan pembelajaran, kegiatan pembelajaran dan evaluasi pembelajaran.

Menurut Malayu (2005:34), kinerja (prestasi kerja) adalah suatu hasil kerja yang dicapai seseorang dalam melaksanakan tugas-tugas yang dibebankan kepadanya yang didasarkan atas kecakapan, pengalaman dan kesungguhan serta waktu. Kinerja adalah tingkat keberhasilan seseorang atau kelompok orang dalam melaksanakan tugas dan tanggungjawabnya serta kemampuan untuk mencapai tujuan dan standar yang telah ditetapkan. Sulistyorini (2011). 
Sallis (2006:170), kinerja guru yang diharapkan dapat mendongkrak kualitas dan relevansi pendidikan, dalam implementasinya di lapangan tergantung dari banyak faktor yang mempengaruhinya dan saling berkaitan, misalnya faktor komunikasi kepala sekolah dan iklim kerja. Kepemimpinan kepala sekolah sangat menentukan mutu, tanpa kepemimpinan yang baik proses peningkatan mutu tidak dapat dilakukan dan diwujudkan

Menurut Pidarta (Ondi Saondi 2010:4), guru sebagai pekerja merupakan pribadi yang berkembang harus memiliki kemampuan yang meliputi unjuk kerja, penguasaan materi, penguasaan profesional keguruan dan pendidikan, penguasaan cara-cara menyesuaikan diri melaksanakan tugasnya.

Menurut Sahertian (Kusmianto 1997:49) menyatakan bahwa, standar kinerja guru berhubungan dengan kualitas guru dalam menjalankan tugasnya seperti: (1) bekerja dengan siswa secara individual, (2) persiapan dan perencanaan pembelajaran, (3) pendayagunaan media pembelajaran, (4) melibatkan siswa dalam berbagai pengalaman belajar, dan kepemimpinan yang aktif dari guru. Kinerja guru mempunyai spesifikasi tertentu. Kinerja guru dapat dilihat dan diukur berdasarkan spesifikasi/kriteria kompetensi yang harus dimiliki oleh setiap guru. Berkaitan dengan kinerja guru, wujud perilaku yang dimaksud adalah kegiatan guru dalam proses pembelajaran yaitu bagaimana kemampuan seorang guru dalam merencanakan pembelajaran, melaksanakan kegiatan pembelajaran, dan menilai hasil belajar.

Kenyataan di lapangan menunjukkan bahwa kinerja guru Sekolah Dasar masih dikategorikan rendah. Hal ini dibuktikan berdasarkan Rekap Nilai PKG Guru di Kecamatan Mataram yang menunjukkan keadaan kinerja guru SD Negeri di Kecamatan Mataram dengan kategori baik sebesar $31 \%$, kategori cukup 50\%, dan kategori kurang sebesar 19\%. (Rekap nilai PKG Guru di Kecamatan Matarm).

Rendahnya kinerja guru seperti yang disebutkan di atas tentu menjadi perhatian bersama agar kinerja guru tersebut dapat ditingkatkan. Salah satu faktor yang dapat meningkatkan kinerja guru adalah komunikasi kepala sekolah. Hal ini sesuai dengan hasil penelitian yang dilakukan oleh Daroni (2007), menunjukkan bahwa terdapat Hubungan yang signifikan antara keefektifan komunikasi kepala sekolah dengan kinerja guru.

Faktor Komunikasi kepala sekolah dapat meningkatkan disiplin guru yaitu dengan menyampaikan sumber informasi di sekolah yang sangat dibutuhkan oleh guru-guru, agar informasi yang disampaikan dapat terlaksana. Nawawi (Maisah 2013:140), menyatakan "komunikasi adalah proses penyampaian dan penerimaan informasi yang menjadi salah satu sumber daya untuk menjaga, memelihara, memajukan dan mengembangkan organisasi secara dinamis sesuai dengan tujuannya".

Menurut Jensen, $\mathrm{T}$ (Fajar, 2009:31), mengemukakan "komunikasi merupakan suatu proses dimana sumber mentransmisikan pesan kepada penerima melalui beragam saluran." Kemudian Rogers (Fajar, 2009), mengemukakan komunikasi adalah "Proses di mana suatu ide di alihkan dari sumber kepada suatu penerima atau lebih dengan maksud untuk megubah tingkah laku mereka".

Menurut Thoha (2012:167), menyatakan bahwa komunikasi adalah 
suatu proses penyampaian dan penerimaan berita atau informasi dari seseorang ke orang lain. Suatu komunikasi yang tepat tidak bakal terjadi, kalau tidak penyampai berita tadi menyampaikan secara patut dan penerima berita menerimanya tidak dalam bentuk distorsi. Bentuk komunikasi dapat dilihat dari berbagai sudut pandang masing-masing pakar menurut pengalaman dan bidang studinya. Komunikasi terbagi atas empat macam tipe, yaitu komunikasi intrapersonal, komunikasi interpersonal, komunikasi publik, dan komunikasi masa.

Kepala sekolah adalah seorang guru yang seharusnya mempunyai kemampuan untuk memimpin segala sumber daya yang ada pada suatu sekolah sehingga dapat didayagunakan secara maksimal untuk mencapai tujuan bersama. Berdasarkan Peraturan Menteri Pendidikan Nasional No. 13 Tahun 2007 tanggal 17 April 2007 Tentang Standar Kepala Sekolah/Madrasah, kepala sekolah harus memiliki kompetensi yakni: kompetensi kepribadian, kompetensi manajerial, kompetensi kewirausahaan, kompetensi supervisi, dan kompetensi sosial. Kelima standar kompetensi tersebut terintegrasi di dalam kinerja kepala sekolah.

Berdasarkan pengertian di atas dapat disimpulkan bahwa komunikasi kepala sekolah adalah proses penyampaian informasi (pesan) sebagai komunikator salah satu komponen pendidikan, tenaga fungsional dan pendidik profesional yang diberi tugas tambahan dan tanggungjawab memimpin, membentuk suatu jaringan informasi oftimal untuk mengarahkan suatu proses perencanaan, pelaksanaan, penilaian dan tindak lanjut kegiatan pembelajaran kepada komunikan (guru)

Urgensi dan signifikansi fungsi dan peranan kepala sekolah didasarkan pada pemahaman bahwa keberhasilan sekolah merupakan keberhasilan kepala sekolah. Oleh karena itu, kepala sekolah perlu memiliki kompetensi yang disyaratkan agar dapat merealisasikan visi dan misi yang diemban sekolahnya. Dalam paradigma baru manajemen pendidikan, kepala sekolah minimal harus mampu berfungsi sebagai edukator, manager, administrator, supervisor, leader, inovator dan motivator (EMASLIM).

Kepala sekolah sebagai pemimpin harus mampu mengambil keputusan yang cepat dan tepat, memberikan petunjuk dan pengawasan, meningkatkan kemauan dan kemampuan tenaga kependidikan, membuka komunikasi dua arah dan mendelegasikan tugas.Wahjosumijo (2011), mengemukakan bahwa kepala sekolah sebagai pemimpin harus memiliki karakter khusus yang mencakup kepribadian, keahlian dasar, pengalaman dan pengetahuan profesional, serta pengetahuan administrasi dan pengawasan. Hal ini menggambarkan bahwa iklim organisasi sebagai beberapa keadaan atau kondisi dalam satu rangkaian yang secara langsung atau tidak langsung, sadar atau tidak sadar, dapat mempengaruhi karyawan. Iklim kerja terdiri dari iklim secara fisik dan iklim secara psikologis. Secara fisik misalnya keamanan, kebersihan, kenyamanan, kondisi sarana dan prasarana organisasi (sekolah). Iklim psikologis meliputi lima dimensi, yaitu: Responsibility (tanggung jawab), identity (identitas), warmth (kehangatan), support (dukungan), dan conflict (konflik). 
Faktor lain yang dapat mempengaruhi kinerja guru adalah iklim kerja organisasi sekolah. Penelitian yang dilakukan Andi (2014), menyimpulkan bahwa iklim kerja sekolah berpengaruh positif terhadap kinerja guru, artinya bahwa semakin baik iklim kerja organisasi sekolah maka akan semakin baik kinerja guru. Hal senada dinyatakan oleh Librawati (2013), dalam peneliannya disimpulkan bahwa iklim kerja berpengaruh positif terhadap kinerja guru.

Iklim kerja organisasi sekolah
yang kondusif harus mampu
memberikan rasa kenyamanan kerja
dari semua komponen yang ada. Sebagai anggota organisasi sekolah dituntut untuk mampu mengembangkan kreativitas dan kepercayaan dari semua warga sekolah yang ada. Hisrich \& Peters (Mulyasa, 2013), berbicara mengenai perilaku yang mencakup pengambilan inisiatif, pengorganisasian, mereorganisasi mekanisme sosial dan situasi keadaan praktek, dan penerimaan resiko/kegagalan.

Lunenburg \& Ornstein (2000:7374) mengemukakan bahwa iklim organisasi ialah suatu kualitas lingkungan total dalam suatu organisasi yang ditunjukkan dengan bermacam-macam sifat antara lain: terbuka, sibuk, hangat, santai, informal, dingin, impersonal, bermusuhan, kaku, dan tertutup. Perilaku dalam organisasi bukan hanya fungsi formal kebutuhan dan motivasi individu. Suatu organisasi harus dapat memperhatikan penilaian atau tanggapan anggota organisasi mengenai pentingnya aspek-aspek hubungan kerja dalam membentuk nilai-nilai organisasi.

Iklim dapat dirasakan, tapi tidak dapat disentuh. Iklim juga dipengaruhi oleh hampir semua hal yang terjadi dalam suatu organisasi. Jika organisasi ingin berhasil dalam mewujudkan citacita dan tujuannya secara utuh dan sempurna, maka dibutuhkan individuindividu yang handal sebagai sumber daya yang akan memegang kendali organisasi. Agar sumber daya manusia di dalam organisasi dapat bekerja secara optimal dan memiliki loyalitas yang tinggi maka organisasi harus dapat menciptakan iklim yang baik dan menyenangkan.

Menurut Pace \& Faules (2006), iklim komunikasi organisasi merupakan gabungan presepsi-presepsi mengenai pristiwa komunikasi, perilaku manusia, respons pegawai terhadap pegawai lainnya, harapanharapan, konflik-konflik antarpersonal dan kesempatan bagi pertumbuhan organisasi. Iklim komunikasi meliputi presepsi-presepsi mengenai pesan dan pristiwa yang berhubungan dengan pesan yang terjadi di dalam organisasi. Menurut Redding yang dikutip oleh Pace \& Faules, iklim organisasi untuk menunjukan kepada anggota organisasi bahwa organisasi tersebut mempercayai mereka dan memberi mereka kebebasan dalam mengambil resiko, mendorong mereka dan memberikan mereka tanggung jawab dalam mengerjakan tugas, menyediakan informasi yang terbuka serta mendengarkan dengan penuh perhatian serta memperoleh informasi yang dapat dan terus terang dari anggota organisasi serta aktif memberikan penyuluhan kepada anggota organisasi sehingga mereka dapat melihat keterlibatan mereka penting bagi penentuan sebuah keputusan.

\section{B. METODE PENELITIAN}

Penelitian ini dilaksankan di SD Negeri yang ada di Kecamatan 
Mataram Kota Mataram. Penelitian ini menggunakan pendekatan Ex Post Facto (meneliti peristiwa yang telah terjadi; tidak dapat memberi perlakuan terhadap variabel bebas) dan jenis korelasional, dimana peneliti menggambarkan fenomena yang diamati dengan lebih detail menggunakan data-data berupa data kuantitatif. Penelitian ini menguji keterkaitan antar variabel penelitian serta mengukur pengaruh variabel bebas $(\mathrm{X})$ dengan variabel terikat $(\mathrm{Y})$. Penelitian ini membahas tentang pengaruh komunikasi kepala sekolah dan iklim kerja organisasi sekolah terhadap kinerja guru di SD Negeri di Kecamatan Mataram Kota Mataram. Populasi penelitian ini adalah seluruh guru PNS SD Negeri di Kecamatan Mataram Kota Mataram yang berjumlah 300 guru. Sampel dalam penelitian ini sebanyak 60 guru yang diambil dari anggota populasi dengan memberikan peluang yang sama untuk menjadi anggota sampel dengan dengan teknik sampling sederhana secara acak (teknik simple random sampling).

Pengujian validitas menggunakan rumus teknik korelasi product moment Pearson yaitu:

$r x y=\frac{N \sum X Y-\left(\sum X\right)\left(\sum Y\right)}{\sqrt{\left\{N \sum X^{2}-\left(\sum X\right)^{2}\right\}\left\{N \sum Y^{2}-\left(\sum Y\right)^{2}\right\}}}$

dengan rxy merupakan koefisien korelasi antara variabel $\mathrm{X}$ dan variabel Y, $N$ merupakan jumlah sampel yang diuji coba, $X$ adalah skor-skor tiap butir soal untuk setiap individu uji coba, dan $Y$ adalah skor total tiap individu uji coba. Untuk mengetahui reliabilitas seluruh tes digunakan rumus Alfa Cronbach sebagai berikut:

$$
r_{11}=\left(\frac{n}{n-1}\right)\left(1-\frac{\sum \sigma_{1}^{2}}{\sigma_{1}^{2}}\right.
$$

dengan $\mathrm{r}_{11}$ adalah reliabilitas, $\mathrm{n}$ jumlah soal, $\sum \sigma_{1}^{2}$ adalah jumlah varian skor tiap-tiap item dan $\sigma_{1}{ }^{2}$ adalah varian total.

Langkah berikutnya adalah melaksanakan uji persyaratan analisis data yang meliputi uji normalitas, homogenitas data, multikolinieritas dan autokorelasi dan dilanjutkan dengan pengujian hipotesis.

Perhitungan nilai uji statistik $\mathbf{F}$ dan nilai statistik $\mathbf{t}$ dalam penelitian ini menggunakan program excel. Pengaruh secara kuantitatif antara masing-masing variabel bebas $\mathrm{X}_{1}$ dan $\mathrm{X}_{2}$ terhadap variabel terikat $\mathrm{Y}$ dihitung dengan menganalisis bentuk persamaan regresi linier sederhana, dengan model persamaan:

$$
\hat{\mathbf{Y}}=\mathbf{a}+\mathbf{b}_{1} \mathbf{X}_{1} \text {. }
$$

Keterangan:

$$
\begin{array}{ll}
\mathrm{a} & =\text { konstanta regresi } \\
\mathrm{b}_{1} & =\text { faktor konstanta }_{1} \\
\mathrm{X}_{1} & =\text { variabel bebas }_{1}
\end{array}
$$

Kemudian analisis dilanjutkan dengan menganalisis bentuk persamaan regresi linier ganda dengan model persamaan:

$$
\hat{\mathbf{Y}}=\mathbf{a}+\mathbf{b}_{1} \mathbf{X}_{1}+\mathbf{b}_{2} \mathbf{X}_{2} \text {. }
$$

Keterangan:

a $=$ konstanta regresi

$\mathrm{b}_{1}=$ faktor konstanta $\mathrm{X}_{1}$

$\mathrm{b}_{2}=$ faktor konstanta $\mathrm{X}_{2}$

$\mathrm{X}_{1}=$ variabel bebas 1

$\mathrm{X}_{2}=$ variabel bebas 2

Hipotesis statistik dalam penelitian ini adalah:

$$
\begin{aligned}
& \mathrm{H}_{0}: \mathrm{ry}_{1} \leq 0 \\
& \mathrm{H}_{1}: \mathrm{ry}_{1}>0
\end{aligned}
$$




$$
\begin{aligned}
& \mathrm{H}_{0}: \mathrm{ry}_{2} \leq 0 \\
& \mathrm{H}_{1}: \mathrm{ry}_{2}>0 \\
& \mathrm{H}_{0}: \mathrm{Ry}_{12} \leq 0 \\
& \mathrm{H}_{1}: \mathrm{Ry}_{12}>0
\end{aligned}
$$

\section{HASIL PENELITIAN}

Berdasarkan analisis desfriptif, diperoleh data seperti yang ditunjukkan pada Gambar berikut:

\section{HASIL DAN PEMBAHASAN}

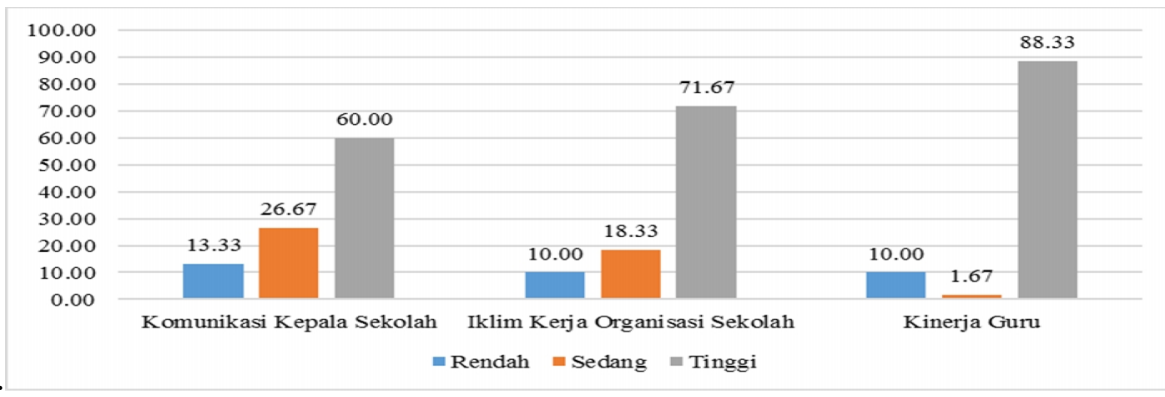

Berdasarkan Gambar di atas diketahui bahwa $13,33 \%$ responden menyatakan komunikasi kepala sekolah SD Negeri di Kecamatan Mataram Kota Mataram dalam kategori rendah, 26,67\% menyatakan dalam kategori sedang, $60 \%$ menyatakan dalam kategori tinggi, $10 \%$ responden menyatakan iklim kerja organisasi sekolah di Kecamatan Mataram Kota Mataram dalam kategori rendah, 18,33\% menyatakan dalam kategori sedang, dan $71,76 \%$ menyatakan dalam kategori tinggi, $10 \%$ responden menyatakan kinerja guru SD Negeri di
Kecamatan Mataram Kota Mataram dalam kategori rendah, 1,67\% menyatakan dalam kategori sedang, dan $88,33 \%$ menyatakan dalam kategori tinggi.

Sebelum analisis data, terlebih dahulu dilakukan uji normalitas, homogenitas, multikolinieritas, dan autokorelasi. Dari hasil uji yang dilakukan menunjukkan bahwa semua data telah memenuhi syarat untuk dilakukan uji hipotesis dengan menggunakan uji statistik. Hasil uji statistik dapat dijelasikan sebagai berikut.

\begin{tabular}{|c|c|c|c|c|}
\hline \multirow[b]{2}{*}{ Model } & \multicolumn{2}{|c|}{ Koefisien } & \multirow{2}{*}{$t_{\text {hitung }}$} & \multirow{2}{*}{ Sig. } \\
\hline & Nilai & Standar Kesalahan & & \\
\hline Konstan (a) & 21,495 & 4,973 & 4,322 & 0,001 \\
\hline Komunikasi (b) & 1,058 & 0,085 & 12,480 & 0,001 \\
\hline
\end{tabular}

1. Pengaruh Komunikasi Kepala Sekolah terhadap Kinerja Guru.

Tabel 1. Pengaruh Komunikasi Kepala Sekolah Terhadap Kinerja Guru SDN di Kecamatan Mataram

Berdasarkan hasil analisis diperoleh koefisien arah regresi b sebesar 1,058, dan konstanta (intercept) a sebesar 21,495. Dengan demikian bentuk pengaruh antara Komunikasi Kepala Sekolah $\left(\mathrm{X}_{1}\right)$ terhadap Kinerja
Guru (Y) ditunjukkan oleh persamaan regresi $\hat{\mathrm{Y}}=21,495+1,058 \mathrm{X}_{1}$. Hasil pengujian signifikansi dan linearitas persamaan tersebut disajikan pada tabel sebagai berikut. 
Tabel 2. Tabel Anova Hasil Analisis Uji Signifikansi Persamaan $\hat{Y}=21,495+$ $1,058 \mathrm{X}_{1}$

\begin{tabular}{|l|l|r|r|r|r|r|}
\hline \multicolumn{2}{|l|}{ Model } & Jumlah Kuadrat & df & $\begin{array}{c}\text { Rerata } \\
\text { Kuadrat }\end{array}$ & F $_{\text {hitung }}$ & Sig. \\
\hline 1 & Regresi & 3415.548 & 1 & 3415.548 & 155,759 & 0,001 \\
\cline { 2 - 7 } & Residual & 1271.852 & 58 & 21.928 & & \\
\cline { 2 - 7 } & Total & 4687.400 & 59 & & & \\
\hline \multicolumn{7}{|l|}{$1,058 X_{1}$ tersebut adalah perubahan satu } \\
\hline
\end{tabular}

Dari hasil perhitungan pada tabel di atas diketahui bahwa harga $\mathrm{F}=155,759$ pada taraf signifikansi $(\mathrm{p})=0,001$. Dengan demikian dapat disimpulkan bahwa Ho yang mengatakan bahwa persamaan regresi $\hat{\mathrm{Y}}=\hat{\mathrm{Y}}=21,495+$ $1,058 \mathrm{X}_{1}$ tidak signifikan ditolak. Berdasarkan hasil tersebut, maka persamaan regresi $\hat{Y}=21,495+1,058 X_{1}$ signifikan dan bersifat linear. Dengan demikian pemahaman yang terkandung dalam persamaan regresi $\hat{Y}=21,495+$ unit pada komunikasi kepala sekolah $\left(\mathrm{X}_{1}\right)$ akan diikuti oleh perubahan 1,058 unit pada kinerja guru sekolah dasar (Y) pada arah yang sama dengan intercept (konstanta) sebesar 21,495.

Besar pengaruh komunikasi terhadap kinerja guru diperoleh berdasarkan hasil analisis yang ditunjukkan pada Tabel sebagai berikut.

Tabel 3. Besaran pengaruh Komunikasi Kepala Sekolah terhadap Kinerja Guru SDN di Kecamatan Mataram

\begin{tabular}{|c|c|c|c|c|c|}
\hline Model & $\mathrm{R}$ & $\mathrm{R}^{2}$ & $\mathrm{R}^{2}$ Terkoreksi & $\begin{array}{c}\text { Standar } \\
\text { Kesalahan }\end{array}$ & $\begin{array}{c}\text { Hasil Uji Durbin- } \\
\text { Watson }\end{array}$ \\
\hline 1 & $0,854^{\mathrm{a}}$ & 0,729 & 0,724 & 4,683 & 1,238 \\
\hline
\end{tabular}

Berdasarkan tabel di atas diperoleh nilan $\mathrm{R}^{2}=0,729$ artinya bahwa sebesar $72,9 \%$ komunikasi kepala sekolah mempengaruhi kinerja guru SD Negeri di Kecamatan Mataram Kota Mataram sedangkan sisanya dipengaruhi oleh faktor lain.
2. Pengaruhantara iklim kerja organisasi sekolah terhadap kinerja guru

Rumusan hipotesis statistik kedua ialah Ho $: \rho \mathrm{yx}_{2}=0$; artinya tidak terdapat pengaruh posilif antara iklim kerja organisasi sekolah $\left(\mathrm{X}_{2}\right)$ terhadap kinerja guru (Y). Hasil analisis data ditunjukkan pada Tabel sebagai berikut.

Tabel 4. Pengaruh Iklim Kerja Organisasi Sekolah Terhadap Kinerja Guru SDN di Kecamatan Mataram

\begin{tabular}{|l|r|r|r|r|}
\hline \multirow{2}{*}{ Model } & \multicolumn{2}{|c|}{ Koefisien } & \multirow{2}{*}{$t_{\text {hitung }}$} & \multicolumn{1}{c|}{ Sig. } \\
\cline { 2 - 3 } Konstan $(a)$ & Nilai & Standar Kesalahan & & 1,489 \\
\hline Iklim Kerja $(b)$ & 6,489 & 4,358 & & 17,678 \\
\hline
\end{tabular}

Berdasarkan hasil perhitungan diperoleh koefisien arah regresi $b$ sebesar 1,007, dan konstanta (intercept) a sebesar 6,489. Dengan demikian bentuk pengaruh antara iklim kerja organisasi sekolah $\left(\mathrm{X}_{2}\right)$ 
terhadap kinerja guru (Y) ditunjukkan oleh persamaan regresi $\hat{Y}=6,489+$ $1,007 \mathrm{X}_{2}$. Hasil pengujian signifikansi dan linearitas persamaan tersebut disajikan pada Tabel 5.

Tabel 5 Tabel Anova Hasil Analisis UjiSignifikansi Persamaan $\hat{\mathrm{Y}}=6,489+1,007 \mathrm{X}_{2}$.

\begin{tabular}{|l|l|r|c|r|r|r|}
\hline \multicolumn{2}{|l|}{ Model } & Jumlah Kuadrat & $\mathrm{df}$ & Rerata Kuadrat & $\mathrm{F}_{\text {hitung }}$ & \multicolumn{1}{c|}{ Sig. } \\
\hline 1 & Regresi & 3953,666 & 1 & 3953,666 & 312,528 & 0,001 \\
\cline { 2 - 7 } & Residual & 733,734 & 58 & 12,651 & & \\
\hline & Total & 4687,400 & 59 & & & \\
\hline
\end{tabular}

Dari hasil perhitungan pada tabel di atas diketahui bahwa F sebesar 312.528 pada taraf signifikansi $(\mathrm{p})=0,001$. Dengan demikian dapat disimpulkan bahwa Ho yang mengatakan bahwa persamaan regresi $\hat{Y}=6,489+1,007 \mathrm{X}_{2}$ tidak signifikan ditolak. Berdasarkan hasil tersebut, maka persamaan regresi $\hat{Y}=6,489+1,007 \mathrm{X}_{2}$ signifikan dan bersifat linear. Dengan demikian pemahaman yang terkandung dalam tersebut adalah perubahan satu unit pada iklim kerja organisasi sekolah $\left(\mathrm{X}_{2}\right)$ akan diikuti oleh perubahan 1,007 unit pada kinerja guru (Y) pada arah yang sama dengan intercept (konstanta) sebesar 6,489.

Besar pengaruh komunikasi terhadap kinerja guru diperoleh berdasarkan hasil analisis yang ditunjukkan pada Tabel sebagai berikut.

Tabel 6. Besaran pengaruh Iklim Kerja Organisasi kepala Sekolah terhadap Kinerja Guru SDN di Kecamatan Mataram

\begin{tabular}{|l|r|r|r|r|r|}
\hline Model & \multicolumn{1}{|c|}{$\mathrm{R}$} & \multicolumn{1}{c|}{$\mathrm{R}^{2}$} & $\mathrm{R}^{2}$ terkoreksi & $\begin{array}{c}\text { Standar } \\
\text { Kesalahan }\end{array}$ & $\begin{array}{c}\text { Hasil Uji } \\
\text { Durbin-Watson }\end{array}$ \\
\hline 1 & $0,918^{\mathrm{a}}$ & 0,843 & 0,841 & 3,557 & 1,665 \\
\hline
\end{tabular}

Berdasarkan tabel di atas diperoleh nilan $\mathrm{R}^{2}=0.843$ artinya bahwa sebesar $84,3 \%$ iklim kerja organisasi sekolah mempengaruhi kinerja guruSD Negeri di Kecamatan Kota Mataram sedangkan sisanya dipengaruhi oleh faktor lain.

\section{Pengaruh Antara Komunikasi} Kepala Sekolah dan Iklim Kerja Organisasi sekolah terhadap Kinerja

\section{Guru.}

Rumusan hipotesis statistik ialah Ho : $\mathrm{R}_{\mathrm{y} 12}=0$; artinya tidak terdapat pengaruh posilif antara komunikasi kepala sekolah $\left(\mathrm{X}_{1}\right)$ dan iklim kerja organisasi sekolah $\left(\mathrm{X}_{2}\right)$ secara bersamasama terhadap kinerja guru (Y). Hasil analisis data ditunjukkan pada Tabel sebagai berikut.

Tabel 7 Pengaruh Komunikasi Kepala Sekolah dan Iklim Kerja Organisasi Sekolah Secara Bersama-Sama Terhadap Kinerja Guru SDN di Kecamatan Mataram

\begin{tabular}{|l|c|c|c|c|}
\hline \multirow{2}{*}{ Model } & \multicolumn{2}{|c|}{ Koefisien } & \multirow{2}{*}{$t_{\text {hitung }}$} & \multirow{2}{*}{ Sig. } \\
\cline { 2 - 3 } Konstan $(a)$ & Nilai & Standar Kesalahan & & 0,958 \\
\hline
\end{tabular}




\begin{tabular}{|l|l|l|l|l|}
\hline Komunikasi $(b 1)$ & 0,452 & 0,081 & 0,365 & 5,574 \\
\hline Iklim Kerja (b2) & 0,702 & 0,072 & 0,640 & 9,780 \\
\hline
\end{tabular}

Berdasarkan hasil perhitungan diperoleh koefisien arah regresi $b_{1}$ sebesar 0,452, $b_{2}$ sebesar 0,702 dan konstanta (intercept) a sebesar 3,43. Dengan demikian bentuk pengaruh antara komunikasi kepala sekolah $\left(\mathrm{X}_{1}\right)$ daniklim kerja organisasi sekolah $\left(\mathrm{X}_{2}\right)$ terhadap kinerja guru (Y) ditunjukkan oleh persamaan regresi $\hat{\mathrm{Y}}=3,43+$ $0,452 X_{1}+0,702 X_{2}$. Hasil pengujian signifikansi dan linearitas persamaan tersebut disajikan pada Tabel 8 .

Tabel 8 Hasil Pengujian Signifikansi Persamaan Regresi $\hat{Y}=3,43+0,452 X_{1}+$ $0,702 \mathrm{X}_{2}$

\begin{tabular}{|l|l|r|r|r|r|r|}
\hline \multicolumn{2}{|l|}{ Model } & Jumlah Kuadrat & df & $\begin{array}{c}\text { Rerata } \\
\text { Kuadrat }\end{array}$ & F Fitung & Sig. \\
\hline \multirow{3}{*}{1} & Regresi & 4212,490 & 2 & 2106,245 & 252,797 & 0,001 \\
\cline { 2 - 7 } & Residual & 474,910 & 57 & 8,332 & & \\
\cline { 2 - 7 } & Total & 4687,400 & 59 & & & \\
\hline
\end{tabular}

Dari hasil perhitungan pada tabel di atas, dapat diketahui bahwa $\mathrm{F}$ sebesar 252,797 pada taraf signifikan $(\mathrm{p})=$ 0,001. Dengan demikian dapat disimpulkan bahwa Ho yang mengatakan bahwa persamaan regresi $\hat{\mathrm{Y}}=3,43+0,452 \mathrm{X}_{1}+0,702 \mathrm{X}_{2}$ tidak signifikan ditolak. Berdasarkan hasil tersebut, maka persamaan regresi $\hat{\mathrm{Y}}=$ $3,43+0,452 \mathrm{X}_{1}+0,702 \mathrm{X}_{2}$ signifikan dan bersifat linear. Dengan demikian pemahaman yang terkandung dalam persamaan regresi $\hat{Y}=3,43+0,452 \mathrm{X}_{1}$
$+0,702 \mathrm{X}_{2}$ tersebut adalah perubahan satu unit pada komunikasi kepala sekolah $\left(\mathrm{X}_{1}\right)$ daniklim kerja organisasi sekolah $\left(\mathrm{X}_{2}\right)$ akan diikuti oleh perubahan 0,452 dan 0,702 unit pada Kinerja Guru(Y) pada arah yang sama dengan intercept. (konstanta) sebesar 3,43 .

Besar pengaruh komunikasi terhadap kinerja guru diperoleh berdasarkan hasil analisis yang ditunjukkan pada Tabel sebagai berikut.

Tabel 9. Besaran pengaruh Komunikasi Kepala Sekolah dan Iklim Kerja Organisasi Sekolah Secara Bersama-Sama Terhadap Kinerja Guru SDN di Kecamatan Mataram.

\begin{tabular}{|l|c|r|r|r|r|}
\hline Model & $\mathrm{R}$ & \multicolumn{1}{|c|}{$\mathrm{R}^{2}$} & $\mathrm{R}^{2}$ Terkoreksi & $\begin{array}{c}\text { Standar } \\
\text { Kesalahan }\end{array}$ & $\begin{array}{c}\text { Hasil Uji } \\
\text { Durbin-Watson }\end{array}$ \\
\hline 1 & 0,948 & 0,899 & 0,895 & 2,886 & 1,422 \\
\hline
\end{tabular}

Berdasarkan Tabel di atas diperoleh nilan $\mathrm{R}^{2}=0,899$ artinya bahwa sebesar 89,9\% komunikasi dan iklim kerja organisasi sekolah secara bersama-sama mempengaruhi kinerja guru SD Negeri di Kecamatan Kota Mataram sedangkan sisanya dipengaruhi oleh faktor lain.
Dengan demikian dapat disimpulkan bahwa ada pengaruh positif komunikasi kepala sekolah dan iklim kerja organisasi sekolah terhadap kinerja guru SDN di Kecamatan Mataram Kota Mataram. Hal ini mengandung makna bahwa komunikasi kepala sekolah daniklim kerja organisasi sekolahsecara 
bersama-sama konsisten dan stabil memberikan sumbangan positif

\section{PEMBAHASAN}

Berdasarkan hasil pengujian hipotesis pertama ditemukan bahwa terdapat pengaruh yang positif antara komunikasi kepala sekolah terhadap kinerja guru SDN di Kecamatan Mataram Kota Mataram. Simpulan tersebut menunjukkan bahwa makin sering dilaksanakannya komunikasi oleh kepala sekolah dapat meningkatkan kinerja guru di SDN di Kecamatan Mataram Kota Mataram. Hal ini sejalan dengan hasil penelitian Rahawarin (2015) mengungkapkan bahwa: terdapat pengaruh positif antara komunikasi kepala sekolah terhadap kinerja guru di SMA di Kabupaten Maluku.

Dari koefisien determinasinya $\mathrm{R}^{2}$ $=0,729$ artinya bahwa sebesar 72,9\% komunikasi mempengaruhi kinerja guru SD Negeri di Kecamatan Kota Mataram, sedangkan sisanya dipengaruhi oleh faktor lain. Pengaruh antara komunikasi kepala sekolah terhadap kinerja guru tetap memiliki pengaruh yang positif meskipun dilakukan pengontrolan terhadap variabel iklim kerja organisasi sekolah. Dengan kata lain bila iklim kerja organisasi sekolah dibuat tetap (dikontrol), maka komunikasi kepala sekolah dapat memberikan kontribusi yang baik terhadap kinerja guru.

Berdasarkan hasil pengujian hipotesis kedua ditemukan bahwa terdapat pengaruh yang positif antara iklim kerja organisasi sekolah terhadap kinerja guru. Simpulan tersebut menunjukkan bahwa makin baik iklim kerja organisasi sekolahnya maka kinerja guru SDN di Kecamatan Mataram Kota Mataram semakin baik. Besarnya kontribusi iklim kerja organisasi sekolah terhadap kinerja guru SDN di Kecamatan Mataram Kota Mataram sebesar $84,3 \%$ sedangkan terhadap kinerja gurupada sekolah dasar.

sisanya dipengaruhi oleh faktor lain. Pengaruh antara iklim kerja organisasi sekolah terhadap kinerja guru tetap memiliki pengaruh yang positif meskipun dilakukan pengontrolan terhadap variabel komunikasi kepala sekolah. Dengan kata lain bila komunikasi kepala sekolah dibuat tetap (dikontrol), maka iklim kerja organisasi sekolah dapat memberikan kontribusi yang baik terhadap kinerja guru SDN di Kecamatan Mataram Kota Mataram.

Pengaruh antara iklim kerja organisasi sekolah terhadap kinerja guru dinyatakan oleh persamaan regresi $\hat{\mathrm{Y}}=6,489+1,007 \mathrm{X}_{2}$ Dengan demikian pemahaman yang terkandung dalam persamaan $\hat{\mathrm{Y}}=6,489+1,007 \mathrm{X}_{2}$ tersebut adalah perubahan satu unit pada iklim kerja organisasi sekolah $\left(\mathrm{X}_{2}\right)$ akan diikuti oleh perubahan 1,007 unit pada kinerja guru (Y) pada arah yang sama dengan intercept(konstanta) sebesar 6,489. Data menunjukkan bahwa pengaruh positif antara iklim kerja organisasi sekolah terhadap kinerja guru merupakan salah satu faktor lain yang kuat memberi kontribusi terhadap kinerja guru.

Dari hasil analisis instrumen iklim kerja organisasi sekolah diperoleh data bahwa skor tertinggi pada instrument No. 20 yang berbunyi Kepala sekolah memberikan perhatian yang adil dan merata berupa materi/non materi kepada bawahan. Ini menggambarkan hal-hal yang bersifat emosional dari seorang guru atau tanggapan seorang guru yang ditunjukkan melalui perilakunya ketika ada yang memberikan penghargaan kepadanya dikarenakan profesinya. Selanjutnya skor terendah pada instrumen No. 30 yang berbunyi: saya rasa tidak perlu melakukan penilaian proses selama pembelajaran, karena akan membuangbuang waktu saja. Skor rendah 
menunjukkan $\quad 40 \%$ guru tidak melakukan penilaian proses. Hal ini mengindikasikan kinerja guru perlu mendapat pembinaan. Penilaian proses sangat penting untuk mengetahui perkembangan prestasi dan sikap peserta didik selama belajar. Selama ini penekanan yang sangat menonjol, baik dalam proses pembelajaran maupun dalam pelaksanaan penilaiannya, diberikan pada domain kognitif. Domain afektif dan psikomotor agak terabaikan. Dampak yang terjadi, seperti yang menjadi sorotan masyarakat akhir-akhir ini, lembagalembaga pendidikan menghasilkan lulusan yang kurang memiliki sifat positif sesuai nilai-nilai yang berlaku, dan kurang terampil untuk menjalani kehidupan dalam masyarakat lingkungannya. Ketiga domain ini perlu mendapat penekanan yang seimbang dalam proses pembelajaran dan penilaian. Dengan demikian, penilaian proses perlu dilaksanakan dengan sebaik-baiknya, dan hasil penilaiannya perlu dimanfaatkan dan ditindaklanjuti. Menurut Niko (dalam Depdiknas), penilaian atau evaluasi dalam bidang pendidikan adalah suatu proses memberi pertimbangan tentang nilai berkaitan dengan murid, metode mengajar, atau program pengajaran.

Berdasarkan hasil pengujian hipotesis ketiga ditemukan bahwa terdapat pengaruh yang positif antara komunikasi kepala sekolah dan iklim kerja organisasi sekolah secara bersama-sama terhadap kinerja guru Sekolah Dasar Negeri di Kecamatan Mataram Kota Mataram.

Hubungan komunikasi kepala sekolah dan iklim kerja organisasi sekolah secara bersama-sama dengan variabel terikat yang dinyatakan dalam persamaan regresi $\hat{\mathrm{Y}}=3,43+0,452 \mathrm{X}_{1}$ $+0,702 X_{2}$ signifikan dan bersifat linear. Dengan demikian pemahaman yang terkandung dalam persamaan regresi $\hat{Y}$
$=3,43+0,452 \mathrm{X}_{1}+0,702 \mathrm{X}_{2}$ tersebut adalah perubahan satu unit pada komunikasi kepala sekolah daniklim kerja organisasi sekolah akan diikuti oleh perubahan 0,452 dan 0,702 unit pada kinerja guru pada arah yang sama dengan intercept. (konstanta) sebesar 3,43. Kontribusi komunikasi kepala sekolah daniklim kerja organisasi sekolah secara bersama-sama terhadap kinerja guru SDN di Kecamatan Mataram Kota Mataram sebesar 89,9\% sedangkan sisanya dipengaruhi oleh faktor lain.

Berdasarkan analisis instrumen komunikasi kepala sekolah dan iklim kerja organisasi sekolah diperoleh data bahwa skor tertinggi (selalu) terdapat pada variabel komunikasi kepala sekolah seperti kepala sekolah memeriksa kesiapan ruang, alat dan media pembelajaran, kepala sekolah memperhatikan dengan seksama pelaksanaan proses pembelajaran secara runtut, kepala sekolah memperhatikan ketika guru menyampaikan kompetensi yang akan dicapai, kepala sekolah mengamati dengan seksama guru melaksanakan pembelajaran yang bersifat kontekstual, kepala sekolah memperhatikan guru melaksanakan pembelajaran sesuai dengan alokasi waktu yang direncanakan, kepala sekolah mengamati dengan seksama ketika guru menumbuhkan partispasi aktif siswa melalui interaksi guru,siswa,dan sumber belajar, kepala sekolah mengamati dengan seksama ketika guru melakukan penilaian akhir sesuai dengan kompetensi/tujuan, kepala sekolah mengamati dengan seksama ketika guru melaksanakan tindak lanjut dengan memberikan arahan atau kegiatan atau tugas sebagai bagian remidi/pengayaan, kepala sekolah meminta seorang guru untuk mendemonstrasikan model pembelajaran. 


\section{DAFTAR PUSTAKA}

Carudin. 2011. Pengaruh kepemimpinan kepala sekolah dan iklim kerja sekolah terhadap kinerja guru. INVOTEC, Volume VII, No. 2, Agustus 2011: 131

Rivai,Veithzal. 2009. Manajemen Sumber Daya Manusia untuk Perusahaan. Edisi kedua. Jakarta; PT. Raja Grafindo Persada.

Saondi, Ondi dan Aris Suherman. 2010. Etika Profesi Keguruan. Bandung: PT Refika Aditama.

Sulistyorini. 2011. Memahami Konsep Kinerja Guru. http://blog.tp.ac.id/ memahami-konsep-kinerja-guru

Sallis, Edward. 2006. Total Quality Management in Education Alih Bahasa: Ahmad Al Riyadi, "Manajemen Mutu Pendidikan",Yogyakarta: Ircisod.

Daroni. 2011. Hubungan Keefektifan Komunikasi Kepala Sekolah Dan Iklim Organisasi Dengan Kinerja Guru di SD Negeri Se Kecamatan Margadana Kota Tegal. Tesis tidak dipublikasikan. Semarang: PPs Magister Manajemen Pendidikan Universitas Negeri Semarang

Maisah. 2013.Manajemen Pendidikan. Jakarta: Gaung Persada Press Group

Fajar, Marhaeni. 2009. Ilmu Komunikasi Teori Dan Prakti. Yogyakarta. Graham Ilmu
Wahjosumidjo. 2011. Kepemimpinan Kepala Sekolah. Jakarta: Raja Grafindo Persada

Andi, P., dkk. 2014. Pengaruh Persepsi Guru Tentang Gaya Kepemimpinan Kepala Sekolah dan Iklim Kerja Terhadap Kinerja Guru. E-Journal Jurusan Pendidikan Ekonomi Universitas Pendidikan Ganesha Singaraja.Vol.4 No. 1.

Librawati, dkk. 2013. Analisis Pengaruh Sikap Profesionalisme, Iklim Kerja Sekolah, dan Gaya Kepemimpinan Kepala Sekolah terhadap Kinerja Guru SMP Negeri di Kecamatan Sukawati. E-Journal Program Pasca Sarjana Universitas Pendidikan Ganesha Volume 4

Mulyasa. 2013. Menjadi Kepala Sekolah Profesional. Bandung : PT Remaja Rosdakarya.

Lunenburg F. C. dan Ornstein, A.C. 2000. Educational Administration: Conceps and Practice. London. Thomas Learning Berkshire House

Pace R. Wayne and Faules, Don F,2000. ROSDA. Bandung

Rahawarin, C.,dkk. 2015. Pengaruh Komunikasi, Iklim Organisasi dan gaya Kepemimpinan Transformasional Kepala sekolah Terhadap Kinerja Guru SMA. EJournal Program Pasca Sarjana Universitas negeri Yogyakarta Volume 3 No.2. 